\title{
LARANGAN PERKAWINAN BEDA AGAMA DALAM KOMPILASI HUKUM ISLAM PERSPEKTIF HAK ASASI MANUSIA
}

\author{
Danu Aris Setiyanto \\ Universitas Islam Negeri Sunan Kalijaga Yogyakarta | Jl. Laksda Adisucipto, \\ Caturtunggal, Depok, Sleman, Daerah Istimewa Yogyakarta 5528। \\ danuaris07@gmail.com
}

\begin{abstract}
This article discusses the prohibition interreligious marriage as regulated in Kompilasi Hukum Islam from the perspective of human rights discourse. There are two perspectives of human rights discourse when applied to the issue of interreligious marriage. The first is those who believe that concept of human rights is anthropocentric. Thus, prohibition of interreligious marriage in Kompilasi Hukum Islam contravenes individual freedom because the only aspect that counts in Islamic marriage is intention to realize compassion and care (rahmah). The second is the group who believes that human rights should not be contradictory to religious principles. Since Indonesia by constitution acknowledge religion as mentioned in Pancasila and Constitution article 29, prohibiting interreligious marriage is justifiable. In Islamic perspective, the prohibition of interreligious marriage is in accordance with the concept of maslahah of protection one's faith which is prioritized over individual wellbeing. Thus, theological basis of marriage comes first at the expense of human rights.
\end{abstract}

Keywords: Human rights, prohibition interreligious marriage, Kompilasi Hukum Islam.

Abstrak: Tulisan ini membahas tentang larangan perkawinan beda agama dalam Kompilasi Hukum Islam perspektif hak asasi manusia. Berkaitan dengan hak asasi manusia, terdapat dua pandangan yang berbeda tentang larangan perkawinan beda agama dalam Kompilasi Hukum Islam: Pertama, kelompok yang menekankan nilai-nilai HAM yang berpusat pada antroposentris, yang menganggap bahwa perkawinan beda agama yang diatur dalam KHI mengurangi kebebasan yang bersifat individual untuk membentuk keluarga, maka perkawinan beda agama seharusnya diperbolehkan karena searah dengan tujuan dan spirit kehadiran Islam yaitu rahmah. Kedua, kelompok yang menyatakan 
bahwa HAM yang melingkup kawin beda agama harus sesuai dengan prinsip-prinsip agama. Indonesia yang merupakan berdasarkan negara Ketuhanan tercantum dalam sila pancasila dan UUD 1945 Pasal 29, sehingga larangan perkawinan beda agama adalah hal yang benar karena sesuai dengan agama Islam bahwa kemaslahatan menjaga agama lebih diutamakan daripada maslahah kemanusiaan. Dalam hal ini, mereka lebih menekankan landasan teologis dalam sebuah perkawinan daripada antroposentris.

Kata Kunci: Hak asasi manusia, perkawinan beda agama, Kompilasi Hukum Islam.

\section{Pendahuluan}

Salah satu isu panas dan kontroversial yang menggegerkan umat Islam Indonesia adalah fenomena nikah beda agama (NBA). Angka-angkanya tiap tahun meningkat tajam. Karena begitu krusialnya, pada tahun 1980-an dan diulang pada tahun 2005, Majelis Ulama Indonesia (MUI) memfatwakan keharaman pernikahan lintas iman. Namun anehnya, meski secara de jure fatwa keagamaan itu dikumandangkan keras oleh lembaga itu, secara de facto fenomena itu terus bergulir dan tidak dapat dibendung. ${ }^{1}$

Agama di satu sisi dianggap sebagai sebuah hak pribadi yang otonom. Namun, di sisi lain dalam masyarakat, hak pribadi yang otonom itu memiliki implikasi sosial yang kompleks dan sensitif dalam masyarakat. Masing-masing penganut agama meyakini bahwa ajaran dan nilai-nilai yang dianutnya harus ditegakkan dalam kehidupan bermasyarakat dan berbangsa. Dalam konteks ini, agama sering kali menjadi potensi konflik dalam kehidupan masyarakat yang plural. Selain itu, ia juga sering menjadi problematik ketika berhadapan dengan masalah pelaksanaan hak asasi manusia. $^{2}$

Selain itu, kepentingan negara yang dianggap memiliki kekuasan untuk mempengaruhi perkawinan beda agama di Indonesia. Dalam hal ini, Indonesia memiliki landasan yuridis yaitu

I Mohammad Monib dan Islah Bahrawi, Islam dan Hak Asasi Manusia dalam Pandangan Nucholish Madjid, (Jakarta: Gramedia Pustaka Utama, 20I I), I52

${ }^{2}$ Anshari Thayib at.all (ed), HAM dan Pluralisme Agama, (Surabaya: PKSK, 1997), i. 
Undang-undang Perkawinan dan Kompilasi Hukum Islam. Undang-undang berlaku umum untuk seluruh rakyat Indonesia apapun agamanya, sedangkan Kompilasi Hukum Islam secara khusus dan lebih spesifik untuk orang Islam. Oleh sebab itu, merupakan hal yang menarik untuk dikaji dalam artikel ini tentang pasal-pasal dalam Kompilasi Hukum Islam (selanjutnya bisa disebut $\mathrm{KHI}$ ) tentang nikah beda agama perspektif hak asasi manusia.

\section{Pengertian Perkawinan Beda Agama}

Sebelum adanya UU No. 1 Tahun 1974 dan sebelum adanya Kompilasi Hukum Islam, isu perkawinan beda agama sudah mendapatkan perhatian yang serius sejak masa penjajahan Belanda. Beberapa aturan perkawinan telah dibuat pemerintah Belanda. Salah satu aturan perkawinan yang dibuat adalah terkait dengan perkawinan dilakukan oleh dua orang yang berbeda golongan asal daerah atau berbeda agama. Pada saat itu pemerintah Belanda saat itu memberikan pengaturan dalam bentuk Penetapan Raja tanggal 29 Desember 1896 No.158 (Stb 1898 No.158) yang merupakan peraturan tentang Perkawinan Campuran atau Regeling op de Gemengde Huwelijken (GHR). ${ }^{3}$ Berdasarkan penjelasan Sisruwadi tentang Staatblad 1896 No. 158 bahwa perkawinan beda agama pada awalya disebut perkawinan campuran. Perkawinan beda agama hanyalah salah satu dari jenis perkawinan campuran. ${ }^{4}$

Perihal tentang perkawinan beda agama sudah tercantum dalam GHR Pasal 1. Dalam Pasal 1 GHR dinyatakan bahwa perkawinan campuran adalah perkawinan antar orang-orang yang di Indonesia tunduk kepada hukum yang berlainan. Perbedaan yang dimaksud dalam pasal ini mencakup dua perbedaan hukum,

${ }^{3}$ Sri Wahyuni, Perkawinan Beda Agama di Luar Negeri Kajian Filosofis, Yuridis, Prosedural, dan Sosiologis, (SUKA-Press: Yogyakarta, 2014), I49-I50.

4 Perkawinan dalam Staatblad tersebut ada empat jenis, yaitu: perkawinan campuran internasional, perkawinan campuran antar tempat, perkawinan campuran antar golongan, dan perkawinan campuran antar agama. Sisruwadi, Praktek Perkawinan Beda Agama dalam Masyarakat Indonesia, slide dipresentasikan dalam seminar sehari yang disampaikan oleh Kepala Dinas Kependudukan dan Pencatatan Sipil Kota Yogyakarta, 4. 
yaitu perbedaan agama dan perbedaan kewarganegaraan. ${ }^{5}$ Selain itu juga ada dalam Pasal 7 ayat (2) GHR yang menegaskan bahwa perbedaan agama, bangsa atau asal itu sama sekali bukanlah halangan perkawinan. Hal ini menunjukkan bahwa sebelum adanya undang-undang perkawinan, perkawinan dapat dilakukan tanpa melihat perbedaan agama, bangsa atau asal. Perkawinan beda agama sebelum adanya undang-undang perkawinan adalah tindakan hukum yang sah yang diatur dalam GHR dan pelaksanaannya dicatatkan di Kantor Pencatatan Sipil. ${ }^{6}$

Definisi perkawinan beda agama seakan tak disepakati oleh ahli hukum setelah adanya undang-undang perkawinan. Beberapa penafsiran tentang perkawinan beda agama beragam, sebagian pihak menafsirkan bahwa perkawinan beda agama dilarang secara tegas dan sebagian lain menyatakan bahwa perkawinan beda agama masih dapat dilakukan di Indonesia karena tidak ada aturan yang jelas dan tegas. Perbedaan inilah yang merupakan salah satu penyebab adanya pelaksanaan perkawinan beda agama di masyarakat dengan berbagai motif dan bentuknya.

Dalam undang-undang perkawinan, beberapa pasal yang terkait dengan perkawinan beda agama terdapat dalam Pasal 2, Pasal 8 (f), Pasal 57, dan Pasal 66. Adanya beberapa Pasal di atas menunjukkan bahwa perkawinan beda agama telah diatur dalam beberapa Pasal UU Perkawinan.

Pasal 2 ayat (1) Undang-undang perkawinan menegaskan bahwa perkawinan yang sah adalah perkawinan yang dilakukan menurut hukum masing-masing agamanya dan kepercayaannya itu. Pasal ini memberikan pengertian bahwa perkawinan beda agama pada dasarnya tidaklah diperkenankan karena perkawinan yang sah adalah yang dilakukan oleh orang yang memiliki kesamaan agama dan kepercayaan. Pasal ini juga menegaskan bahwa perkawinan harus dilakukan menurut ketentuan agama,

${ }^{5}$ Anshary, Hukum Perkawinan di Indonesia: Masalah-masalah Krusial, (Pustaka Pelajar: Yogyakarta, 20I0), 50.

${ }^{6}$ Sri Wahyuni, Perkawinan Beda Agama di Luar Negeri..., 150. 
dan ketentuan yang dilarang oleh agama berarti dilarang juga oleh undang-undang perkawinan, sedangkan dalam Pasal 8 ditegaskan bahwa perkawinan dilarang antara dua orang yang mempunyai hubungan yang oleh agamanya atau peraturan lain yang berlaku dilarang kawin.

M. Ashari menjelaskan apabila yang melakukan perkawinan adalah perempuan beragama Kristen dengan laki-laki beragama Islam, maka tidaklah mungkin kemudian dilakukan akad dua kali, sekali menggunakan agama Kristen dan sekali menggunakan agama Islam. Menurutnya, perbuatan hukum hanya bisa dilakukan dengan sekali akad untuk menjamin kepastian hukum. Apabila dilakukan dua kali akad maka justru tidak ada kepastian hukum. Selain itu, perkawinan tersebut juga sangatlah rumit dalam alat bukti, jika perkawinan menurut Islam maka dicatatkan perkawinannya tersebut di KUA, dan apabila dia melakukan perkawinan secara Kristen maka dicatatkan di Kantor Catatan Sipil. Dua akad perkawinan inilah yang juga bisa dipermasalahkan sebagai bukti perbuatan hukum. ${ }^{7}$ Wiratni juga menjelaskan bagi orang yang beragama Islam, dalam melangsungkan perkawinan harus berdasarkan hukum Islam, dan tidak mungkin dirinya kemudian melanggar hukum agama Islam. Hal ini juga berlaku bagi yang beragama lain, yaitu: Kristen, Katolik, Hindu, Budha dan kepercayaannya masing-masing. ${ }^{8}$

Pendapat yang sama juga disampaikan oleh Hilman Hadikusumo, menjelaskan bahwa sahnya perkawinan menurut perundangan diatur dalam pasal 2 ayat (1) UU Nomor 1 Tahun 1974, yang menyatakan: “Perkawinan adalah sah, apabila dilakukan menurut hukum masing-masing agamanya dan kepercayaannya itu". Jadi perkawinan yang sah menurut hukum perkawinan nasional adalah perkawinan yang dilaksanakan menurut tata tertib

\footnotetext{
${ }^{7}$ M. Anshar, Hukum Perkawinan di Indonesia: Masalah-masalah Krusial, 56.

${ }^{8}$ Wiratni Ahmadi, "Hak dan Kewajiban Wanita dalam Keluarga Menurut Undang-undang No. I Tahun 1974 Tentang Perkawinan”, Jurnal Hukum Pro Justitia, Bandung: Vol. 26 No. I, 2008, 370.
} 
aturan hukum yang berlaku dalam agama Islam, Kristen, Katolik, Hindu, Budha. Kata "hukum masing-masing agamanya" berarti hukum dari salah satu agama itu masing-masing, bukan berarti "hukum agamanya masing-masing" yaitu hukum agama yang dianut oleh kedua mempelai atau keluarganya.

Jadi perkawinan yang sah jika terjadi perkawinan antar agama, adalah perkawinan yang dilaksanakan menurut tata tertib aturan salah satu agama, agama calon suami atau agama calon istri, bukan perkawinan yang dilaksanakan oleh setiap agama yang dianut kedua calon suami istri dan atau keluarganya. Jika perkawinan telah dilaksanakan menurut hukum Islam, kemudian dilakukan lagi perkawinan menurut hukum Kristen dan atau hukum Hindu/ Budha, maka perkawinan itu tidak sah, demikian sebaliknya. ${ }^{9}$

Pasal 57 undang-undang perkawinan, menegaskan bahwa perkawinan campuran adalah perkawinan antara dua orang yang di Indonesia tunduk pada hukum yang berlainan, karena perbedaan kewarganegaraan dan salah satu pihak berkewarganegaraan Indonesia. Sehingga dalam hal ini makna perkawinan campuran sebelum dan sesudah adanya undangundang perkawinan mengalami perubahan makna. ${ }^{10}$ Menurut GHR, perkawinan campuran merupakan perkawinan antara dua orang yang beda agama atau beda kewarganegaraannya. Sedangkan dalam undang-undang perkawinan, perkawinan campuran adalah perkawinan yang terjadi antara WNI dan WNA saja. Hal ini menunjukkan bahwa perkawinan sah apabila orang yang melakukan perkawinan berbeda kewarganegaraan tetapi memiliki agama yang sama. ${ }^{11}$

Sirman Dahwal berpendapat bahwa dalam undang-undang perkawinan di Indonesia harus diakui masih terpengaruh dengan hukum peninggalan Belanda. Menurutnya, perkawinan beda

9 Hilman Hadikusuma, Hukum Perkawinan Indonesia menurut Perundangan, Hukum Adat, Hukum Agama, (Bandung: Mandar Maju, 1990), 26-27.

10 M. Anshary, Hukum Perkawinan di Indonesia ..., 50.

"Ibid., 52. 
agama di Indonesia belum diatur sepenuhnya secara jelas dan rinci dalam undang-undang perkawinan, sehingga perkawinan beda agama diatur dan bersandarkan pada hukum sebelumnya. Hal inilah yang digunakan pegangan para hakim di pengadilan dalam mengabulkan permohonan perkawinan beda agama, sehingga bagi pasangan beda agama masih terdapat pilihan hukum (choice of law) untuk melangsungkan perkawinannya. ${ }^{12}$

\section{Perkawinan Beda Agama dalam Kompilasi Hukum Islam}

Pembicaraan al-Qur'an tentang perkawinan beda agama terdapat dalam tiga surat: Pertama, QS. al-Baqarah (2): 221 yang berbicara tentang larangan pria muslim menikah dengan wanita musyrik dan wanita muslimah dinikahkan dengan pria musyrik. Kedua, QS. al-Maidah (5): 5 yang membolehkan pria muslim menikahi wanita Ahli Kitab. Ketiga, QS. al- Mumtahanah, (60): 10 yang menegaskan ketidakhalalan wanita muslimah bagi pria kafir dan sebaliknya. Dalam penafsiran QS. al-Baqarah, (2): 221 di kalangan ortodoksi Islam berkembang pandangan bahwa wanita musyrikah yang tidak boleh dinikahi pria muslim meliputi: wanita penganut paganisme Arab yang menyembah berhala; wanita penganut agama-agama non-samawi yang menyembah bintang, api dan binatang; dan wanita pengikut ateisme dan materialisme. ${ }^{13}$

Dalam KHI, beda agama dalam perkawinan dapat terjadi sebelum dilaksanakan perkawinan dan setelah terjadi perkawinan selama membina dan menjalankan rumah tangga. Perbedaan agama sebelum perkawinan dan terus berjalan saat perkawinan dilangsungkan akan menghasilkan analisis sah tidaknya perkawinan yang terjadi. Sementara perbedaan agama yang muncul setelah akad nikah selama membina dan menjalankan rumah tangga, menghasilkan analisis yang terkait dengan

12 Sirman Dahwal, Hukum Perkawinan Beda Agama dalam Teori dan Praktiknya di Indonesia, (Bandung, Mandar Maju, 20I6), 166.

${ }^{13}$ Nina Mariani Noor dan Ferry Muhammadsyah Siregar (ed), Etika Sosial dalam Interaksi Lintas Agama, (Yogyakarta: Globethics.net., 2014), 45. 
pembatalan perkawinan. ${ }^{14}$ Pembahasan perkawinan beda agama dalam Kompilasi Hukum Islami dibagi menjadi tiga:

1. Beda agama sebagai kekurangan syarat perkawinan

Beda agama yang terjadi dan diketahui sebelum akad nikah oleh Kompilasi Hukum Islam datur dalam Bab VI mengenai larangan perkawinan, pasal 40 dan $44^{15}$, serta Bab X mengenai Pencegahan Perkawinan, Pasal 616. Seorang pria dilarang melangsungkan perkawinan dengan seorang wanita yang tidak beragama Islam, (Pasal 40 huruf c), sementara seorang wanita muslim dilarang melangsungkan perkawinan dengan seorang yang tidak beragama Islam, (Pasal 44). Walaupun bagian ini secara harfiah dari ketentuan mengenai rukun dan syarat perkawinan, namun pasal $18^{17}$ menjelaskan bahwa sesungguhnya Bab VI ini memiliki hubungan dengan Bab IV bagian kedua mengenai calon mempelai.

Antara rukun dan syarat dalam perkawinan, mempunyai konsekuensi hukum yang berbeda apabila dalam suatu perkawinan ternyata ada yang tidak terpenuhi. Ketika rukun nikah yang tidak terpenuhi, maka pernikahan harus dinyatakan batal demi hukum, pernikahan itu sejak dilangsungkan sejak dilangsungkan sudah tidak sah, dan pembatalannya tidak tergantung dari upaya hukum. Upaya hukum hanya untuk mendapatkan kepastian hukum yang diperlukan manakala ada pihak yang meragukannya, namun batalnya nikah harus nikah harus ditetapkan sejak dilaksanakannya akad nikah dimaksud. Ketika syarat yang tidak terpenuhi, maka

\footnotetext{
${ }_{14}$ M. Kasayuda, Perkawinan Beda Agama Menakar Nilai-nilai Keadilan Kompilasi Hukum Islam, (Total Media: Yogyakarta, 2006), 136.

${ }^{15}$ Pasal $40 \mathrm{KHI}$ : "Dilarang melangsungkan perkawinan antara seorang pria dengan seorang wanita karena keadaan tertentu; a. karena wanita yang bersangkutan masih terikat satu perkawinan dengan pria lain; b. seorang wanita yang masih berada dalam masa iddah dengan pria lain; c. seorang wanita yang tidak beragama Islam". Dan Pasal $44 \mathrm{KHI}$ : "Seorang wanita Islam dilarang melangsungkan perkawinan dengan seorang pria yang tidak beragama Islam."

${ }^{16}$ Pasal 6 I KHI: "Tidak sekufu tidak dapat dijadikan alasan untuk mencegah perkawinan, kecuali tidak sekufu karena perbedaan agama atau ikhtilaaf ad-din."

${ }_{17}$ Pasal $18 \mathrm{KHI}$ : "Bagi calon suami isteri yang akan melangsungkan pernikahan tidak terdapat halangan perkawinan sebagaimana diatur dalam bab Vl”.
} 
pembatalannya tergantung dari pengajuan para pihak, dan apabila tidak ada pengajuan, maka pernikahannya dianggap sah. ${ }^{18}$

Konsep ini berakibat bahwa suatu perkawinan yang tidak memenuhi syarat akan terus berlangsung dan dipandang sah karena tidak ada pihak yang mengajukan pembatalan ke pengadilan agama. ${ }^{19}$ Apabila logika ini kita pergunakan, maka perkawinan yang dilangsungkan oleh pihak yag berbeda agama, seyogyanya termasuk dapat dibatalkan.

Kompilasi Hukum Islam tidak menentukan status pernikahan yang dilakukan oleh pasangan yang beda agama yang terjadi saat akad nikah, apakah batal demi hukum atau dapat dibatalkan. Namun perbedaan agama yang terjadi setelah akad nikah berlangsung menjadi salah satu alasan sebuah pernikahan "dapat" dibatalkan.

Pendapat tersebut diambil dengan menghubungkan antara ketentuan Pasal 74 ayat (2) dengan Pasal 75 huruf a. Dalam pasal 74 ayat (2) diatur mengenai ketentuan tentang "batalnya suatu perkawinan" yang dimulai setelah putusan pengadilan agama mempunyai kekuatan hukum yang tetap dan berlaku sejak saat berlangsungnya perkawinan. pasal 75 huruf 1 menentukan bahwa keputusan pengadilan mengenai "pembatalan perkawinan" tidak berlaku surut terhadap perkawinan yang batal karena salah satu dari suami istri murtad. Yang pertama berlaku surut dan yang kedua tidak berlaku surut. ${ }^{20}$

2. Beda agama sebagai alasan pencegahan perkawinan

Pasal 61 dalam Kompilasi Hukum Islam, tidak mempunyai konsekuensi bagi absah tidaknya perkawinan, karena tindakan yang dilakukan adalah pencegahan, sehingga tidak terjadi/belum

18 M. Kasayuda, Perkawinan Beda Agama ..., I36-137.

${ }_{19}$ Pasal 74 ayat (2): "Batalnya suatu perkawinan dimulai setelah putusan Pengadilan Agama mempunyai kekuatan hukum yang tetap dan berlaku sejak saat berlangsungnya perkawinan." 20 Pasal $75 \mathrm{KHI}$ : "Keputusan pembatalan perkawinan tidak berlaku surut terhadap: a. perkawinan yang batal karena salah satu dari suami atau istri murtad; b. anak-anak yang dilahirkan dari perkawinan tersebut; c. pihak ketiga sepanjang mereka memperoleh hak-hak dengan beriktikad baik, sebelum keputusan pembatalan perkawinan mempunyai kekuatan hukum yang tetap." 
terjadi akad nikah. ${ }^{21}$ Pencegahan diajukan kepada pengadilan agama dalam daerah hukum di mana perkawinan akan dilangsungkan dengan memberikan kepada PPN setempat. ${ }^{22}$ Yang dapat mengajukan pencegahan adalah keluarga dalam garis keturunan ke bawah, saudara, wali nikah, wali pengampu dari mempelai. ${ }^{23}$ Suami atau istri yang masih terikat dalam perkawinan dengan salah satu calon mempelai dapat mengajukan pencegahan perkawinan dengan salah satu mempelai dapat mengajukan pencegahan perkawinan. ${ }^{24}$ Bahkan pejabat yang bertugas mengawasi perkawinan berkewajiban mencegah perkawinan bila rukun dan syarat perkawinan tidak terpenuhi. ${ }^{25}$

Kompilasi Hukum Islam menempatkan pencegahan perkawinan begitu penting dengan menempatkannya sebagai salah satu kewajiban pejabat yang bertugas mengawasi perkawinan. Hal ini dapat dimengerti karena jika sebuah perkawinan yang cacat terjadi, maka dampaknya tidak sekedar memisahkan dua manusia yang telah terlanjur membangun cintanya dalam sebuah rumah tangga, tetapi bisa melahirkan problem sosial bagi anak yang dillahirkan dari perkawinan tersebut. ${ }^{26}$

Amanah KHI kepada pejabat dengan mewajibkan melakukan pencegahan perkawinan yang tidak sesuai dengan hukum Islam

${ }^{21}$ Pasal $61 \mathrm{KHI}$ : "Tidak sekufu tidak dapat dijadikan alasan untuk mencegah perkawinan, kecuali tidak sekufu karena perbedaan agama atau ikhtilâf ad-dîn."

${ }^{22}$ Pasal 65 KHI: “ (I) Pencegahan perkawinan diajukan kepada Pengadilan Agama dalam daerah hukum tempat perkawinan akan dilangsungkan dengan memberitahukan juga kepada Pegawai Pencatat Nikah. (2) Kepada calon-calon mempelai diberitahukan mengenai permohonan pencegahan perkawinan dimaksud dalam ayat (I) oleh Pegawai Pencatat Nikah. ${ }^{23}$ Pasal $62 \mathrm{KHI}$ : (I) Yang dapat mencegah perkawinan ialah para keluarga dalam garis keturunan lurus ke atas dan ke bawah, saudara, wali nikah, wali pengampu dari salah seorang calon mempelai, dan pihak pihak yang bersangkutan. (2) Ayah kandung yang tidak pernah melaksanakan fungsinya sebagai kepala keluarga tidak gugur hak kewaliannya untuk mencegah perkawinan yang akan dilakukan oleh wali nikah yang lain.

${ }^{24}$ Pasal $63 \mathrm{KHI}$ : "Pencegahan perkawinan dapat dilakukan oleh suami atau istri yang masih terikat dalam perkawinan dengan salah seorang calon istri atau calon suami yang akan melangsungkan perkawinan."

${ }^{25}$ Pasal 64: "Pejabat yang ditunjuk untuk mengawasi perkawinan berkewajiban mencegah perkawinan bila rukun dan syarat perkawinan tidak dipenuhi."

${ }^{26}$ M. Kasayuda, Perkawinan Beda Agama Menakar ..., 138. 
memberi jaminan bahwa sebuah perkawinan yang dilakukan di hadapan PPN adalah perkawinan yang sah. ${ }^{27}$

3. Beda agama sebagai alasan pembatalan perkawinan

Pasal 75 bagian dari pasal-pasal yang mengatur tentang pembatalan perkawinan, yang salah satu alasan pembatalannya adalah "salah satu dari suami istri murtad". Keputusan pembatalan perkawinan karena alasan salah satu dari suami istri murtad, tidak berlaku surut. Ketentuan ini mempunyai dampak bahwa sebuah perkawinan yang salah satu pihaknya murtad akan dibatalkan pernikahannya terhitung sejak putusan dijatuhkan. Jadi murtadnya seseorang "tidak otomatis" membuat pernikahannya menjadi batal, ia tetap berlangsung dan dipandang sebagai ikatan perkawinan yang sah sampai ada putusan pengadilan yang tidak boleh berlaku surut. ${ }^{28}$

Pada sisi lain pengadilan baru dapat membatalkan sebuah perkawinan apabila ada permohonan yang diajukkan oleh pihak yang berhak, tidak setiap orang yang mengetahui adanya salah satu suami istri yang murtad berhak mengajukan pembatalan. ${ }^{29}$

Pembatalan perkawinan karena salah satu pihak suami atau istri murtad tidak termasuk dalam alasan batal atau dapat dibatalkannya suatu perkawinan. Namun dilhat dari mulai berlakunya pembatalan perkawinan yang tidak bisa berlaku surut, maka alasan ini termasuk bagian yang dapat dibatalkan. ${ }^{30}$ Alasan lainnya terlihat adanya posisi pejabat yang berwenang mengawasi pelaksanaan perkawinan yang hanya diberi hak, bukan kewajiban, berbeda dengan posisinya dalam kasus pencegahan perkawinan.

${ }^{27}$ lbid.

${ }^{28}$ Ibid.

${ }^{29}$ Berdasarkan pasal $73 \mathrm{KHI}$ yang dapat mengajukan permohonan perkawinan yaitu: I) para keluarga dalam garis keturunan lurus ke atas dan ke bawah dari suami atau isteri, 2) suami atau isteri, 3) pejabat yang berwenang mengawasi pelaksanaan perkawinan menurut Undangundang, 4) para pihak yang berkepentingan yang mengetahui adanya cacat dalam rukum dan syarat perkawinan menurut hukum Islam dan Peraturan Perundang-undangan sebagaimana tersebut dalam Pasal 67.

${ }^{30}$ Batalnya suatu perkawinan dimulai sejak putusan Pengadilan Agama mempunyai hukum yang tetap dan berlaku sejak berlangsungnya perkawinan (pasal 74 ayat 2). 
Karena itu KHI menempatkan batalnya perkawinan karena murtadnya salah satu pihak pada kemauan pihak yang berhak mengajukkan pembatalan. ${ }^{31}$

\section{Analisis Hak Asasi Manusia terhadap Larangan Perkawinan Beda Agama dalam Kompilasi Hukum Islam}

Secara terminologi, hak asasi manusia (HAM) berasal dari tiga kata yakni "hak, asasi, dan manusia". Istilah hak berasal dari bahasa Arab al-haq, sedangkan dalam bahasa Inggris, istilah hak identik dengan kata rights. Definisi hak adalah sesuatu yang melekat pada diri manusia, bersifat universal, dan tidak dapat dicabut, serta terkait dengan adanya kewajiban terhadap orang lain. Sedangkan istilah asasi dalam bahasa Arab setara dengan al-asâs, yang dalam bahasa Inggris juga setara maknanya dengan base, fundamental, dan principal. Kesemuanya memiliki arti yang sama, yakni sesuatu yang melekat dan mendasar pada suatu subjek atau objek terentu. Sedangkan istilah manusia dalam bahasa Arab setara dengan alInsân, sedangkan dalam bahasa Inggris setara dengan kata human. ${ }^{32}$

Apabila ketiga rumpun kata di atas digabungkan menjadi satu, terbentuknya term hak asasi manusia (HAM) yang dalam bahasa Arab disebut al-huqûq al-insâniyyah al-asâsiyyah, sedangkan dalam bahasa Inggris populer dengan istilah human rights. Dengan demikian, HAM dapat diartikan hak asasi manusia yang paling fundamental, universal, tidak dapat dicabut, abadi, dan terkait dengan adanya kewajiban. Seseorang tidak dapat memaksakan kehendaknya kepada orang lain karena dibatasi oleh kewajiban yang dipikulnya. Pada gilirannya dapat dikatakan bahwa hakikat HAM merupakan hak fundamental yang melekat pada diri manusia secara kodrati, universal, dan abadi sebagai anugerah Tuhan Yang Maha Esa dan tanpa hak itu manusia tidak dapat hidup sebagai manusia. ${ }^{33}$

\footnotetext{
${ }^{31}$ M. Kasayuda, Perkawinan Beda Agama Menakar..., I4I.

${ }^{32}$ Yusdani, Menuju Figh Progresif, (Yogyakarta: Kaukaba, 20I5), 22-23.

${ }^{33}$ lbid.
} 
Persoalan kawin atau nikah beda agama merupakan persoalan yang menjadi perdebatan dalam hukum keluarga Islam, baik di era klasik, tengah maupun kontemporer. Kawin beda agama merupakan problem dalam hak sipil politik. Sebuah konvensi tentang hak sipil politik diselenggarakan PBB dinyatakan bahwa tidak diperbolehkan adanya campur tangan apapun terhadap diri dan keluarga seseorang. Hal tersebut berimplikasi dalam memilih pasangan hidup, yang pada dasarnya, setiap orang mempunyai kebebasan sendiri yang tidak dibatasi oleh institusi apapun. Persyaratannya adalah sama suka antara kedua pasangan dan tidak merugikan orang lain. Inilah yang disebut HAM dalam perspektif Barat bercorak antroposentris. ${ }^{34}$

Menurut Nurcholish Madjid, ijtihad keagamaan atau keislaman merupakan pasar bebas. Para ulama struktural dalam MUI dan non-struktural di pesantren-pesantren dan aktivis HAM berebut makna dan tafsir atau teks. Ladang luas dan membentang yang mereka kelola berada pada QS. al-Baqarah: 221, alMumtahanah: 10, dan al-Maidah: 5. Inilah tiga surat utama tentang nikah beda agama yang dipersengketakan. Term yang mereka pergulatkan bersifat teologis seperti kafir, syirik, musyrik, dan ahl al-kitâb. ${ }^{35}$

Deklarasi Universal Hak Asasi Manusia PBB menjamin adanya hak berkeluarga (pernikahan). Dalam pasal 16 ayat 1 disebutkan:

“Orang-orang dewasa, baik pria maupun wanita, dengan tidak dibatasi kebangsaan, kewarganegaraan atau agama, berhak untuk mencari jodoh dan membentuk keluarga. Mereka mempunyai hak yang sama dalam soal perkawinan, di dalam dan di kala perceraian."

Sementara pasal 2 berbunyi:

"Perkawinan harus dilakukan hanya dengan cara suka sama suka dari kedua mempelai"

Pasal 3 berbunyi:

${ }^{34}$ Mohammad Monib dan Islah Bahrawi, Islam dan Hak Asasi Manusia..., 134.

${ }^{35}$ Ibid., I53-I 54. 
“Keluarga adalah kesatuan yang sewajarnya serta merupakan inti dari masyarakat dan berhak mendapat perlindungan dari masyarakat dan negara."

Menurut Nurcholish Madjid dan Quraish Shihab, ada tiga motivasi niat luhur para pasangan nikah yang memilki pasangan beda beda agama yang bersinggungan dengan HAM. Motivasi itu adalah (1) membangun biduk rumah tangga dengan tulang rusuknya, (2) memperoleh generasi penerusnya secara baik dan benar, (3) merasakan kebahagiaan sebagai suami istri. Namun, mereka terjepit dan dikepung oleh dua kutub ekstrem: pernikahan sebagai hak pribadi (privat) di satu pihak, dan stigma keharaman dalam perspektif agama-agama (Islam, Yahudi, Kristen, Hindu, dan Budha). ${ }^{36}$

Menurut Nurkholis Madjid, dalam konteks hak asasi manusia untuk berkeluarga atau menikah, pandangan dan dukungan terhadap pernikahan seorang laki-laki muslim dengan perempuan non muslim dalam rumpun ahl al-kitâb merupakan advokasi kemanusiaan. Tidak dapat tidak, mesti ada solusi dan jalan keluar terhadap masalah-masalah yang muncul. Tindakan Nucholish merupakan bentuk pengayoman nilai-nilai kebaikan dan kemaslahatan bagi manusia. Pilihan intelektual dan aksi kecendekiawanan Nurcholish paralel dengan semangat nilai-nilai HAM modern.

Sedangkan dalam Islam yang selama ini dipahami, memilih pasangan adalah tidak bebas mutlak. Bahkan dikatakan dalam sebuah hadisnya, Nabi saw memberi kriteria pilihan yang menempatkan agama pada rangking pertama. Dalam Islam, perkawinan haruslah sesama muslim. Masalah perkawinan beda agama, sebenarnya ada indikasi makruh, sehingga yang dibolehkan pun hanya muslim dengan perempuan ahl al-kitâb (Yahudi dan Nasrani) dan tidak sebaliknya. Bahkan sama sekali dilarang, baik muslim maupun muslimah, menjalin ikatan perkawinan dengan laki-laki maupun perempuan dari orang kafir. Pergulatan konsep

${ }^{36}$ Ibid., I 58. 
ini pada akhirnya telah mempengaruhi perdebatan dalam perumusan Kompilasi Hukum Islam dan Counter of Legal Draft (CLD KHI). ${ }^{37}$

Kalau diperhatikan penjelasan Tim Pengarusutamaan Gender dalam bagian Pengantar dalam pembuatan CLD KHI dapat dipahami bahwa pembolehan perkawinan beda agama ini adalah sekedar dalam rangka menegakkan prinsip-prinsip pluralisme, nasinalisme, HAM, demokrasi dan kemaslahatan yang antroposentris.

Pembolehaan tersebut di atas sepertinya karena didasari oleh suatu keyakinan mereka bahwa masalah perkawinan beda agama adalah masalah ijtihâdi. Pembolehan ini cenderung terlihat bahwa mereka lebih mengutamakan asas kebahagiaan dan manfaat bagi pelaku pernikahan di atas konsekuensi tidak maksimalnya pelaksanaan ajaran agama (dîn) dari masing-masing. Dalam bahasa maqâshid al-syarî'ah, mereka lebih mengutamakan manusianya daripada agamanya. Hal tersebut lebih sesuai dengan konsep dan asas manfaat. ${ }^{38}$

Di sisi lain, para perumus KHI mempunyai asas perkawinan bahwa perkawinan harus terjadi dengan antar muslim. Ini juga berangkat dari konsep ingin mengejar maslahat. Sebagaimana dalam maqâshid al-syarî'ah, dinyatakan bahwa dalam perumusan hukum maka mujtahid harus mempertimbangkan lima hal sekaligus, yakni: 1) agama, 2) jiwa, 3) akal, 4) harta dan 5) keturunan. Mereka lebih memprioritaskan agama daripada kenikmatan jiwa/manusianya. ${ }^{39}$ Mereka yang menolak mutlak perkawinan beda agama menempatkan agama di atas empat komponen yang lain. Dengan demikian, mereka berpendapat bahwa kemaslahatan keempat komponen yang lain harus mengikuti kemaslahatan agama. Dalam kasus beda agama, logika hukum ini tampak. Demi menjaga agamanya (Islamnya), seseorang

${ }^{37}$ Yusdani, Menuju Figh Progresif ..., I 34- I 35.

38 lbid.

${ }^{39}$ Yusdani, Menuju Figh Progresif ..., I 35-1 36. 
harus memilih pasangan sesama muslim. Mereka menempatkan agama sebagai bagian yang non-derogable rights yaitu hak yang tidak dapat dikurangi dalam keadaan tertentu apapun. ${ }^{40}$

Pandangan lain muncul dari Majelis Tarjih dan Tajdid Pimpinan Pusat Muhammadiyah, Azhari menjelaskan secara yuridis nilai-nilai HAM bersumber pada instrumen internasional yang disebut sebagai the International Bill of Human Rights, yang terdiri atas Universal Declaration of Human Rights, the International Covenant on Civil and Political Rights (ICCPR-1966) beserta dua Optional Protocols and the International Covenant on Economic, Social and Cultural Rights (ICESCR-1966). Sekalipun merupakan instrumen internasional, tetapi HAM memiliki dimensi universal dan partikular. Dimensi universal memandang nilai-nilai HAM berlaku berlaku universal sebagaimana diatur dalam Bangkok NGO Declaration pada 27 Maret 1993 yang menyatakan, bahwa: "As human rights are universal concern and are universal in value, the advocacy of human rights cannot be considered to be an encroachment upon national sovereignty." Artinya, nilai-nilai HAM bersifat universal sehingga penegakan HAM tidak dapat dibatasi oleh kedaulatan nasional. ${ }^{41}$

Pada sisi lain, terdapat pula pandangan yang melihat HAM dengan dimensi partikular sebagaimana dianut dalam Vienna Declaration and Programme of Action 23 Juni 1993 yang kemudian diadopsi oleh ASEAN Human Rights Declaration Tahun (AHRD) 2013 atau Piagam HAM ASEAN yang menyatakan: ${ }^{42}$

All human rights are universal, indivisible, and interdependent and interrelated. The international community must treat human rights globally in a fair and equal manner, on the same footing, and with the same

\footnotetext{
40 lbid., 136.

${ }^{41}$ Makalah disampaikan pada Seminar Sehari tentang "Undang-undang Republik Indonesia No. I tahun 1974 tentang Perkawinan, khususnya tentang Perkawinan Beda Agama” yang diselenggarakan oleh Majelis Tarjih dan Tajdid Pimpinan Pusat Muhammadiyah bekerjasama dengan Fakultas Hukum Universitas Muhammadiyah Yogyakarta pada Sabtu, 20 Shafar 1436 H / I 3 Desember 2014 di Yogyakarta, I-2.

42 Ibid., 4.
} 
emphasize. While the significant of national and regional particularities and various historical, cultural, and religious background must be born in mind, it is the duty of states, regardless of their political, economic, and cultural systems, to promote and protect all human rights and fundamental freedoms.

Menurut Azhari, sesuai dengan kedudukan Indonesia sebagai bagian dari negara ASEAN, maka pandangan yang dianut oleh negara Indonesia adalah pandangan HAM yang bersifat partikular sebagaimana disebutkan dalam Piagam HAM ASEAN 2013. Dengan demikian, penegakan HAM oleh negara tetap harus mempertimbangkan kepentingan nasional dan regional serta latar belakang sejarah, kebudayaan, dan agama. Hal itu juga sejalan dengan ketentuan pada Pasal 28J ayat (2) UUD NRI Tahun 1945 yang menyatakan:

Dalam menjalankan hak dan kebebasannya, setiap orang wajib tunduk kepada pembatasan yang ditetapkan dengan undangundang dengan maksud semata-mata untuk menjamin pengakuan serta penghormatan atas hak kebebasan orang lain dan untuk memenuhi tuntutan yang adil sesuai dengan pertimbangan moral, nilai-nilai agama, keamanan, dan ketertiban umum dalam suatu masyarakat demokratis. ${ }^{43}$

Dengan demikian, penegakan HAM di negara Indonesia wajib tunduk pada pembatasan yang ditetapkan dengan UU yang di antaranya harus sesuai dengan pertimbangan nilai-nilai agama. Pembatasan berdasarkan pertimbangan nilai-nilai agama itu sejalan dengan ketentuan Pasal 29 UUD NKRI Tahun 1945 yang menyatakan "Negara berdasar atas Ketuhanan yang Maha Esa yang menimbulkan kewajiban bagi negara untuk menjamin kemerdekaan tiap-tiap penduduk untuk memeluk agamanya masing-masing dan untuk beribadah menurut agamanya dan kepercayaannya itu". ${ }^{44}$

Berdasarkan pemaparan di atas terdapat dua pandangan yang berbeda dalam perkawinan beda agama: Pertama, kelompok yang

${ }^{43}$ Ibid., 4-5.

${ }^{44}$ Ibid., 5. 
menekankan nilai-nilai HAM yang berpusat pada antroposentris akan mengakibatkan bahwa perkawinan yang diatur dalam KHI hanya dianggap mengurangi kebebasan yang bersifat individual untuk membentuk keluarga. Bahkan kelompok ini menganggap bahwa nikah/kawin beda agama searah dengan tujuan dan spirit kehadiran Islam yaitu rahmah. ${ }^{45}$ Kelompok ini lebih menekankan nilai-nilai kemanusian berupa keadilan dan kebebasan untuk menentukan keluarga tanpa batasan agama. Kedua, kelompok yang menyatakan bahwa HAM yang melingkup kawin beda agama harus sesuai dengan prinsip-prinsip agama. ${ }^{46}$ Indonesia yang merupakan berdasarkan negara Ketuhanan tercantum dalam sila pancasila dan UUD 1945 Pasal 29. ${ }^{47}$ Sehingga dalam perkawinan beda agama tidaklah dianggap hal yang benar karena tidak sesuai dengan agama Islam. ${ }^{48}$ Kelompok ini beranggapan bahwa kemaslahatan menjaga agama lebih diutamakan daripada maslahah kemanusiaan. Dalam hal ini, mereka lebih menekankan landasan teologis dalam sebuah perkawinan daripada antroposentris.

\section{Penutup}

Terdapat dua kelompok yang berbeda pendapat tentang larangan perkawinan beda agama dalam Kompilasi Hukum Islam jika dikaitkan dengan hak asasi manusia. Kelompok pertama berpendapat bahwa Kompilasi Hukum Islam sebagai landasan hukum perkawinana beda agama, dianggap tidak sesuai dengan prinsip-prinsip HAM yang universal. Kebebasan beragama seakan menjadi ancaman bagi kelompok pemahaman HAM yang tanpa batas agama di Indonesia. Dengan pendekatan HAM yang

\footnotetext{
${ }^{45}$ Mohammad Monib dan Islah Bahrawi, Islam dan Hak Asasi Manusia..., I 68.

${ }^{46}$ HAM yang bersifat universal harus juga memperhatikan nilai-nilai lokal sebuah bangsa, bukan HAM yang menekankan kebebasan tanpa batas dan melampaui batasan agama.

47 Pasal 29 UUD 1945:"I) Negara berdasar atas Ketuhanan Yang Maha Esa. (2) Negara menjamin kemerdekaan tiap-tiap penduduk untuk memeluk agamanya masing-masing dan untuk beribadat menurut agamanya dan kepercayaannya itu.

${ }^{48} \mathrm{Hal}$ ini seperti fatwa MUI yang menyatakan perkawinan beda agama adalah I) haram dan tidak sah; 2) perkawinan laki-laki muslim dengan perempuan ahlul kitab, menurut qaul mu'tamad, adalah haram dan tidak sah.
} 
antroposentris, maka nikah beda agama adalah sejalan dengan prinsip Islam yaitu rahmah. KHI yang mengatur kawin beda agama perlu adanya perubahan untuk menciptakan keadilan sosial untuk menciptakan kebaikan dan niat baik untuk berkeluarga.

Kelompok kedua berpendapat bahwa HAM seharusnya bersifat terbatas. Terbatas dengan nilai-nilai agama dan aturan lokal suatu daerah atau bangsa. Perkawinan beda agama yang secara teologis dianggap suatu yang makruh atau haram berlaku untuk di Indonesia. Sehingga pelarangan perkawinan beda agama dalam KHI merupakan hal yang wajar dan benar dalam perspektif perundang-undangan, HAM dan norma dalam masyarakat. Kebebasan dalam membentuk keluarga haruslah mengutamakan menjaga agama daripada antroposentris.

\section{Daftar Pustaka}

Ahmadi, Wiratni. "Hak dan Kewajiban Wanita dalam Keluarga Menurut Undang-undang No. 1 Tahun 1974 tentang Perkawinan". Jurnal Hukum Pro Justitia, Bandung: Vol. 26 No. 1,2008

Anshary. Hukum Perkawinan di Indonesia: Masalah-masalah Krusial. Yogyakarta: Pustaka Pelajar, 2010.

Azhari. “Undang-undang Republik Indonesia No. 1 tahun 1974 tentang Perkawinan, khususnya tentang Perkawinan Beda Agama". Seminar. Yogyakarta: Majelis Tarjih dan Tajdid Pimpinan Pusat Muhammadiyah bekerjasama dengan Fakultas Hukum Universitas Muhammadiyah Yogyakarta. Sabtu, 20 Shafar 1436 H / 13 Desember 2014.

Dahwal, Sirman. Hukum Perkawinan Beda Agama dalam Teori dan Praktinya di Indonesia. Bandung: Mandar Maju, 2016.

Hadikusuma, Hilman. Hukum Perkawinan Indonesia menurut Perundangan, Hukum Adat, Hukum Agama. Bandung: Mandar Maju, 1990.

Karsayuda. Perkawinan Beda Agama: Menakar Nilai-nilai Keadilan Kompilasi Hukum Islam. Yogyakarta: Total Media, 2006. 
Monib, Mohammad dan Islah Bahrawi. Islam dan Hak Asasi Manusia Dalam Pandangan Nucholish Madjid. Jakarta: Gramedia Pustaka Utama, 2011

Noor, Nina Mariani dan Ferry Muhammadsyah Siregar (ed). Etika Sosial dalam Interaksi Lintas Agama. Yogyakarta: Globethics.net. 2014.

Sisruwadi. "Praktek Perkawinan Beda Agama dalam Masyarakat Indonesia". Slide. Dipresentasikan dalam seminar sehari yang disampaikan oleh Kepala Dinas Kependudukan dan Pencatatan Sipil Kota Yogyakarta.

Thayib, Anshari at.all (ed). HAM dan Pluralisme Agama. Surabaya: PKSK, 1997.

Wahyuni, Sri. Perkawinan Beda Agama di Luar Negeri Kajian Filosofis, Yuridis, Prosedural, dan Sosiologis. Yogyakarta: SUKA-Press, 2014.

Yusdani. Menuju Figh Keluarga Progesif. Yogyakarta: Kaukaba Dipantara, 2015.

Deklarasi Hak Asasi Manusia (HAM) PBB

Kompilasi Hukum Islam (KHI)

Undang-Undang Dasar 1945 Amandemen

Undang-undang No. 1 Tahun 1974 tentang Perkawinan 